\title{
PNEUMONIA AND EMPYEMA IN CHILDREN
}

\author{
BY \\ DUNCAN MACAULAY \\ From the Royal Edinburgh Hospital for Sick Children
}

(RECEIVED FOR PUBLICATION MARCH 17, 1951)

In 1929 McNeil, Macgregor and Alexander reported in this journal the results of a combined clinical and pathological investigation of pneumonia in childhood. Their report appeared 20 years after the publication of a paper by Dunlop (1908) based on the study of 500 cases of pneumonia treated in the same ward. The present communication records the results of an investigation of 369 cases of pneumonia and 19 cases of empyema treated in the same hospital in 1947, 1948 and 1949, and indicates such changes in these acute respiratory infections as can be ascertained from a comparison of the three series.

\section{Material}

The present series comprises all the cases of acute pneumonia admitted to the three medical wards of the Royal Edinburgh Hospital for Sick Children from April, 1947, to March, 1949, inclusive. The information required has been extracted from the ward records and the diagnoses are based on consideration of all the available data: history, clinical findings, radiographic appearances and pathological reports. The criterion for the diagnosis of pneumonia has been incontestable evidence of pulmonary infiltration. In 28 instances this was determined at necropsy, in 325 cases by radiography, and in the remaining 16 cases by clear-cut physical signs. Several cases registered as pneumonia in the casebooks have been omitted since the evidence was not sufficiently strong to support the diagnosis. On the other hand it is probable that some cases may have been missed, because of unavoidable delays in, for instance, $x$-ray examination. I think these are few, and that the series includes the great majority of the cases of pneumonia encountered in the wards in these years.

I do not intend to reopen the question of the diagnosis of the types of pneumonia in early childhood. The matter has been frequently, if rather inconclusively, discussed by many writers, and Wallace's (1937) comment that 'there is as yet no uniformity of opinion as to the criteria which distinguish bronchopneumonia from alveolar pneumonia in very young children' is probably still true. Since the distinction must be attempted, however, in order to compare the different series, the principle has been adopted in dealing with the present material of regarding those cases of pneumonia which showed signs of a concomitant generalized bronchitis as being instances of bronchopneumonia, and those without such signs as cases of lobar pneumonia. This method of differentiation is based on the observation of McNeil, Macgregor and Alexander (1929) that in bronchopneumonia 'as a rule there is a generalized acute bronchitis affecting bronchi of all sizes throughout both lungs', whereas 'in typical alveolar pneumonia the bronchial walls and the whole framework of the lungs are remarkably free from inflammatory infiltration'. No criterion will meet all possible objections, but this one appears to be, apart from post-mortem examination, the least objectionable. The results obtained from its employment are, as will be shown, in close agreement with those of other observers.

\section{Results}

There are three ways, on the information available, of comparing the present series with the earlier ones.

Incidence of the Types of Pneumonia. Of the 369 cases of pneumonia, 267 were diagnosed by the above standards as lobar pneumonia, and 102 as bronchopneumonia. Fig. 1 shows the number of admissions for each type by yearly groups. Fig. 2 shows the percentages of each type per year of age.

McNeil et al. discuss at some length the common belief that lobar pneumonia is rare under the age of 2 years, and give their reasons for thinking that this is not so. Table 1 shows the incidence of the types of pneumonia encountered in the two series in this age group. The agreement between the two series is close and indicates that the criteria utilized in the present investigation are valid. In 1939 
TABLE 1

InCidence OF Lobar PNeUmonia and BronchoPNeUmonia in ChIIDRen Under 2 Years of AGe

\begin{tabular}{|c|c|c|}
\hline & $\begin{array}{c}\text { Lobar } \\
\text { Pneumonia }\end{array}$ & $\begin{array}{l}\text { Broncho- } \\
\text { pneumonia }\end{array}$ \\
\hline $\begin{array}{c}\text { Present Series } \\
0-1 \text { year }\end{array}$ & $41\left(42 \cdot 7^{\circ}\right)$ & $55\left(57 \cdot 3^{\circ} \mathrm{o}\right)$ \\
\hline $0-2$ years & . $87\left(55 \cdot 1^{\circ}{ }_{0}\right)$ & $71\left(44 \cdot 9^{\circ}{ }_{0}\right)$ \\
\hline $\begin{array}{c}\text { McNeil et al. (1929) } \\
\text { 0-1 year }\end{array}$ & $43\left(41 \cdot 7_{0}^{\circ}\right)$ & $60\left(59 \cdot 3^{\circ}{ }_{0}\right)$ \\
\hline $0-2$ years & . $143\left(56 \cdot 5^{\circ}{ }_{0}\right)$ & $110\left(43 \cdot 5^{\circ}{ }_{0}\right)$ \\
\hline $\begin{array}{l}\text { Total } \\
0-2 \text { years }\end{array}$ & . $230\left(56^{\circ}{ }_{0}\right)$ & $181\left(44^{\circ}{ }_{0}\right)$ \\
\hline
\end{tabular}

McNeil reported on 464 cases of pneumonia admitted to his ward in the 10 years following his first report. He gave the incidence of the two types of pneumonia in children under the age of 2 years in this second series as lobar pneumonia $133(58 \%)$; bronchopneumonia $95(42 \%)$. Thus in the three series, covering a period of nearly $\mathbf{3 0}$ years, from this one hospital, there is a fairly constant proportion of the two types of pneumonia in very young children. In all, 639 cases of pneumonia in children under the age of 2 years have been studied, and the distribution of the types in this not inconsiderable

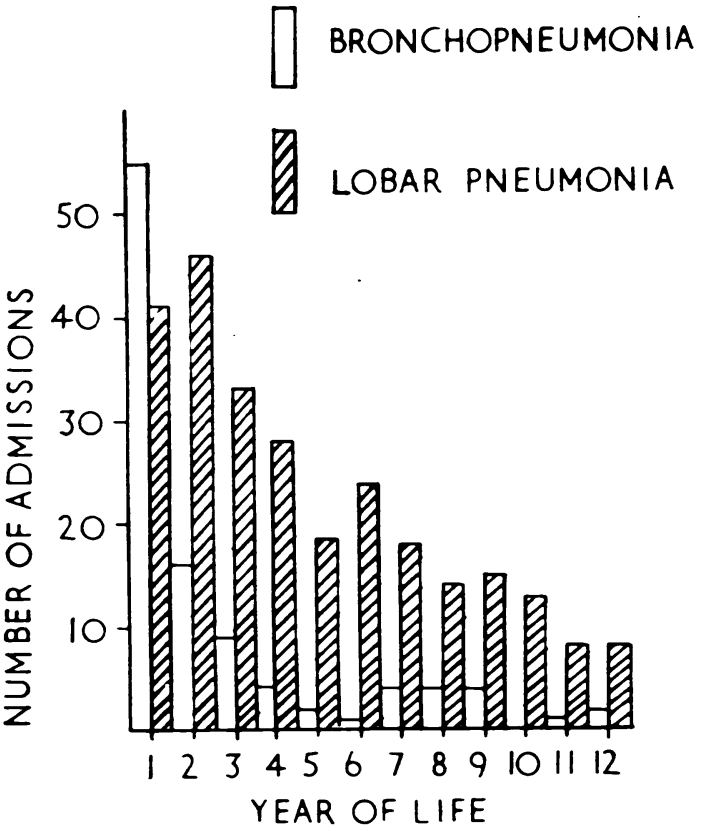

Fig. 1.

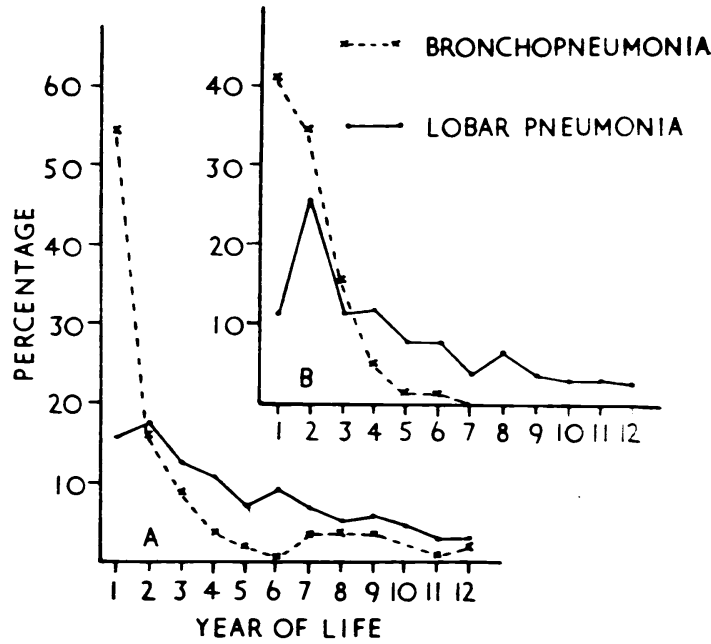

FIG. 2.-Diagram illustrating (A) present series, and (B) McNeil et al. (1929)

number is: lobar pneumonia, $56.8 \%$; bronchopneumonia, $43 \cdot 2 \%$.

That these figures do not represent a local peculiarity, either of the diseases or of the standards of diagnosis, is indicated by Table 2 which gives details of two large series reported from America. The cases of primary pneumonia in children under 2 years of age were distributed as shown. It would appear reasonable to claim that between 50 and $60 \%$ of primary pneumonias in infancy are of the lobar type, and that this proportion has shown no appreciable change in Edinburgh over the past 30 years.

Dunlop's figures for his 1908 series are not comparable with those given above, since his cases of bronchopneumonia included a large number of infants who developed 'secondary' bronchopneumonia in the course of other illnesses such as

TABLE 2

INCIDENCE OF Lobar PNeUmonia aNd BroNchoPNEUMONIA IN CHILDREN IN U.S.A.

\begin{tabular}{|c|c|c|c|}
\hline & $\begin{array}{c}\text { Lobar } \\
\text { Pneumonia }\end{array}$ & $\begin{array}{l}\text { Broncho- } \\
\text { pneumonia }\end{array}$ & Total \\
\hline $\begin{array}{c}\text { Nemir et al. } \\
\text { (1936) }\end{array}$ & 286 & 190 & 476 \\
\hline $\begin{array}{l}\text { Bullowa and } \\
\text { Greenbaum } \\
\text { (1936) }\end{array}$ & 264 & 255 & 519 \\
\hline Total & $550(55 \cdot 3 \%)$ & $445\left(44 \cdot 7^{\circ}, 0\right)$ & 995 \\
\hline
\end{tabular}


TABLE 3

Mortality Rates for lobar Pneumonia, Bronchopneumonia and Bronchitis in Children Admitted to the Royal EDInburgh Hospital for Sick Children 1908-1949

\begin{tabular}{|c|c|c|c|c|c|c|c|c|}
\hline & \multicolumn{2}{|c|}{ Lobar Pneumonia } & \multicolumn{3}{|c|}{ Bronchopneumonia } & \multicolumn{3}{|c|}{ Bronchitis } \\
\hline Series & Deaths & $\begin{array}{l}\text { Mortality } \\
\text { Rate }\end{array}$ & Total & Deaths & $\begin{array}{l}\text { Mortality } \\
\text { Rate }\end{array}$ & Total & Deaths & $\begin{array}{c}\text { Mortality } \\
\text { Rate }\end{array}$ \\
\hline $\begin{array}{l}\text { Dunlop (1908) } \\
0-2 \text { yrs. } \ldots . .45 \\
\end{array}$ & 23 & $26 \cdot 6^{\circ} \mathrm{o}$ & 233 & 57 & $24 \cdot 5 \%$ & - & - & - \\
\hline $2-12$ yrs. . . 102 & 3 & $2 \cdot 9^{\circ} \mathrm{o}$ & 120 & 32 & $26 \cdot 7^{\circ}$ 。 & - & - & - \\
\hline Total ....147 & 15 & $10 \cdot 2^{\circ}$ o & 353 & 89 & $25 \cdot 1^{\circ} \%$ & - & - & - \\
\hline $\begin{array}{l}\text { McNeil et al. (1929) } \\
0-2 \text { yrs. ....143 }\end{array}$ & 21 & $14 \cdot 5^{\circ} \mathrm{o}$ & 110 & 67 & $61^{\circ}$ 。 & 155 & 5 & $3^{\circ} \circ$ \\
\hline $2-12$ yrs. ...243 & 5 & $2 \cdot 1 \%$ & 34 & 11 & $32 \cdot 4 \%$ & 76 & 1 & $1 \cdot 3^{\circ} \%$ \\
\hline Total ....386 & 26 & $6 \cdot 5^{\circ} \circ$ & 144 & 78 & $54^{\circ} \%$ & 231 & 6 & $2 \cdot 5^{\circ}{ }_{0}$ \\
\hline $\begin{array}{l}\text { McNeil }(1939) \\
{ }^{*} 0-2 \text { yrs.....133 }\end{array}$ & 11 & $8 \cdot 3^{\circ}$ o & 95 & 57 & $60^{\circ}$ \% & - & - & - \\
\hline $2-12$ yrs. ...226 & 6 & $2 \cdot 7 \%$ & 10 & 4 & $40^{\circ} \%$ & - & - & - \\
\hline Total ....359 & 17 & $4.5 \%$ & 105 & 61 & $59^{\circ} \circ$ & - & - & - \\
\hline $\begin{array}{l}\text { Present Series } \\
0-2 \text { yrs......87 }\end{array}$ & 3 & $3 \cdot 4 \%$ & 71 & 26 & $36 \cdot 6^{\circ} \%$ & 128 & 8 & $6 \cdot 3^{\circ}$ 。 \\
\hline $2-12$ yrs. . . 180 & 1 & $0.6 \%$ & 31 & 4 & $12 \cdot 9 \%$ & 37 & 0 & - \\
\hline Total ...267 & 4 & $1.5 \%$ & 102 & 30 & $29 \cdot 4 \%$ & 165 & 8 & $4.9^{\circ} \circ$ \\
\hline
\end{tabular}

* Excluding infants under one month of age.

measles or typhoid. It is not possible to determine the number of cases of primary bronchopneumonia from the information given.

Mortality. Table 3 summarizes the data available for the four series reported from this hospital in the past $\mathbf{4 0}$ years. It is evident that there has been a constant decrease in the mortality from lobar pneumonia in the last four decades, until at the present day the mortality in children over the age of 2 years is negligible. (The single death recorded in the present series was of a girl of 11 who had in addition to pneumonia an extremely severe acute nephritis.) This decline in the mortality from lobar pneumonia has been commented on by many observers. Francis (1944), for example, has this to say :

- Over the past decade there has been a remarkable shift in the broad picture of pneumonia on this continent (North America) which has reached its culmination in the past five years. ... About 1925 a decline in mortality from the disease began and was sharply accelerated between 1930 and 1937. . . . It appears that the decreasing mortality was to a large extent related to natural causes.'
Israel, Mitterling, and Flippin (1948) make a similar observation:

'Mortality from lobar pneumonia had declined sharply between 1925 and 1937 , to a far greater degree than could have been due to the limited use of serum therapy.'

Both these reports refer to the further sharp decrease in the mortality of the disease since the introduction of chemotherapy. It may be concluded that lobar pneumonia, in common with a number of other diseases, e.g. scarlet fever, was, even before the discovery of the sulphonamides, undergoing a spontaneous and unexplained decrease in severity.

The wide discrepancy in the mortality rates for bronchopneumonia is rather disconcerting. The two series reported by McNeil are fairly consistent and show the disease to be a very serious one especially in infancy. It seems strange that the mortality in 1947-1949, with all the advantages of chemotherapy and oxygen therapy available in those years, should have been greater than in 1908, especially in view of the sevenfold reduction in 
TABLE 4

INCIDENCE OF EMPYema IN Two SerIEs

\begin{tabular}{|c|c|c|c|}
\hline Author & All Cases of Pneumonia + Empyema & Cases of Empyema & Incidence of Empyema \\
\hline McNeil et al. .. & 619 & 89 & $14 \cdot 4^{\circ}$ 。 \\
\hline$\overline{\text { Present series } . .}$ & 394 & 25 & $6 \cdot 3^{\circ}$ \\
\hline
\end{tabular}

mortality of lobar pneumonia in the two periods. It may be unwise to speculate about this difference, but it seems possible, at least, that the early series included a number of cases which in the later series would have been diagnosed as bronchitis. This suggestion is not intended as a reflection on the diagnostic standards employed by Dunlop, but merely as a reminder that the more recent series have been examined radiographically, and the admittedly difficult differentiation of acute bronchitis from bronchopneumonia has been facilitated by the use of a technique not available to him. If, in the 1929 series of $\mathrm{McNeil}$ et al., the figures for bronchitis and bronchopneumonia are combined, a total mortality rate of $22.4 \%$ is obtained. This is sufficiently close to the rate in the early series, $25 \cdot 1 \%$, to suggest that this explanation may have some validity. In the present series the mortality for the combined catarrhal infections is $14.2 \%$. The reduction is much less striking than in the case of lobar pneumonia and, since there was no significant difference in the rates in the first three series, it may reasonably be attributed mainly to the use of chemotherapy.

Empyema. The 19 cases recorded here comprise all the children treated for empyema in the two years reviewed. Apart from these, there were six cases in which a purulent or sero-purulent exudate was found at necropsy.

Table 4 shows the incidence of empyema in the two series for which information is available. The decline in incidence is marked, and is comparable to that noticed by other writers. Chaplin (1947), for instance, found that after the introduction of sulphonamides the incidence of empyema in acute pneumonia (all types) in infants and children declined from $9.3 \%$ to $3.7 \%$ This represents a decrease in incidence of $60 \%$ in the course of 10 years. The decrease in Edinburgh is of the same order.

Table 5 shows the results of the bacteriological examinations made in the two series. These results are in substantial agreement with other recently reported series (Forbes, 1946; Guthrie and Montgomery, 1947; Hipsley, 1949) in showing the remarkable decline in empyema due to pneumococci, and in the great increase in staphylococcal cases.

\section{Discussion}

From the data presented above it seems legitimate to conclude that (1) the types of pneumonia encountered in this hospital have remained fairly constant over the past 30 years, (2) lobar pneumonia has shown a progressive decrease in mortality since the beginning of the century, and (3) empyema is much less common than formerly and is now rarely due to pneumococci.

The last of these findings is almost certainly (compare Forbes, 1946) due to the employment of sulphonamides and penicillin, though exactly how they have produced this effect is uncertain. The large number of papers on staphylococcal pneumonia and empyema in children published in the past 10 years (for example, Clemens and Weens, 1942; Ladd and Swan, 1943; Riley, 1944; Philips and Kramer, 1945; Blumenthal and Neuhof, 1946; Watkins, Tichenor, Robb and Forbes, 1948; McLetchie, 1949) seems to indicate that staphylococcal infections of the lungs and pleura are not only relatively but absolutely more frequent than before the introduction of chemotherapy. This increase was already noticed before penicillin came

TABLE 5

Results of Bacteriological Examination in Two Series

Organism Recovered

\begin{tabular}{l|c|ccc}
\hline Author & Pneumococcus & Streptococcus & Staphylococcus & Others and Mixed Infections \\
\hline McNeil et al. $\ldots$ & $53(76 \%)$ & $\frac{2(10 \%)}{3(14 \%)}$ & $12(55 \%)$ & $8(11 \%)$ \\
\hline Present series $\ldots$ & $3(14 \%)$ & $4(17 \%)$ \\
\hline
\end{tabular}


TABLE 6

Diagnoses on Admssion to Hospital

\begin{tabular}{|c|c|c|c|c|}
\hline \multirow[b]{2}{*}{ Author } & \multirow[b]{2}{*}{ Total } & \multicolumn{2}{|c|}{ Diagnosis on Admission } & \multirow[b]{2}{*}{ Meningitis } \\
\hline & & Pneumonia & Appendicitis & \\
\hline $\begin{array}{c}\text { Adams and Berger } \\
2-15 \text { years }\end{array}$ & 145 & $66(45 \cdot 5 \%)$ & $25\left(17 \cdot 6^{\circ} \circ\right)$ & $7(4 \cdot 8 \%)$ \\
\hline $\begin{array}{l}\text { Present series } \\
2-12 \text { years }\end{array}$ & 93 & $37\left(40^{\circ} \%\right)$ & $15\left(16^{\circ}{ }_{0}\right)$ & $4(4 \cdot 4 \%)$ \\
\hline
\end{tabular}

into general use and is not primarily related to the emergence of resistant strains of staphylococci.

The decline in the mortality from lobar pneumonia appears to be an instance of the spontaneous variation in severity of a disease, and though the rate of decline has become greater following the use of chemotherapeutic agents, its essential cause is unknown.

With regard to the constancy of the clinical picture presented by these diseases the following figures are of interest. In surveying the present series a note was made of the diagnosis with which each child was referred to hospital by the outside doctor. In $74 \%$ of the cases of acute lobar pneumonia this could be ascertained. In 1922 Adams and Berger published the result of an investigation designed to clarify the differential diagnosis of lobar pneumonia and acute appendicitis in children. They, also, noted the diagnoses with which their patients had been referred to hospital, or where there was no record of these, the diagnoses made in the admitting room. Table 6 shows the figures for the two series. The similarity is striking, and the conclusion seems justifiable that the disease in its early stages presented very much the same appearance in America in 1922 as it did in Scotland in 1947-49. It is of some interest to recall that Wells in 1889 , after a most exhaustive review of the literature on pneumonia from Hippocrates onwards, came to the conclusion that 'there has been no actual change in the type of this disease, and that the pneumonic fever (lobar pneumonia) of today is that of our fathers and of past ages, and will be that of future generations'.

\section{Summary}

Data about the cases of acute respiratory infection admitted to the Royal Edinburgh Hospital for Sick Children from April, 1947, to March, 1949, are presented and compared with those available from earlier reports from this hospital.

The type of disease encountered does not appear to have changed appreciably in the past 30 years, and fairly constant proportions of the two principal types of pneumonia at various ages are shown to have been observed.

The mortality from lobar pneumonia has shown a steady decline from 1908 to 1949 . This decline is largely unexplained.

Staphylococci have replaced pneumococci as the principal cause of acute empyema in this hospital. This change is related to, but not completely explained by, the introduction of chemotherapeutic drugs.

I am indebted to the physicians to the Hospital (Professor R. W. B. Ellis, Dr. D. N. Nicholson and Dr. J. L. Henderson) for permission to consult the records of their cases. I wish to thank Professor Ellis for advice about the presentation of this material.

\section{REFERENCES}

Adams, F. D. and Berger, B. J. (1922). J. Amer. med. Ass., 79, 1809.

Blumenthai, S. and Neuhof, H. (1946). Amer. J. Dis. Child., 72, 691 .

Bullowa, J. G. M. and Greenbaum, E. (1936). Publ. Hlth. Rep., Wash., 51, 1076.

Chaplin, A. E. (1947). Archives of Disease in Childhood, 22, 91 .

Clemens, H. H. and Weens, H. S. (1942). J. Pediat., 20, 281.

Dunlop, G. H. M. (1908). Brit. med. J., 2, 367.

Forbes, G. B. (1946). J. Pediat., 29, 45.

Francis, T. (1944). Canad. J. publ. Hlth., 35, 49.

Guthrie, K. J., and Montgomery, G. L. (1947). Lancet, 2, 752 .

Hipsley, D. (1949). Med. J. Aust., 1, 838.

Israel, H. L., Mitterling, R. C. and Flippin, H. F. (1948). New Eng. J. Med., 238, 205.

Ladd, W. E. and Swan, H. (1943). J. Pediat., 23, 297.

McLetchie, N. G. B. (1949). Canad. med. Ass. J., 60, 352.

McNeil, C. (1939). Edin. med. J., 46, 153.

- Macgregor, A. R. and Alexander, W. A. (1929). Archives of Disease in Childhood, 4, 12, 83, 111, 170, 270.

Nemir, R. L., Andrews, E. T., and Vinograd, J. (1936). Amer. J. Dis. Child., 51, 1277.

Philips, B. and Kramer, B. (1945). J. Pediat., 26, 481.

Riley, C. M. (1944). J. Pediat., 24, 577.

Wallace, H. L. (1937). Brit. med. J., 1, 657.

Watkins, C. G., Tichenor, R. W., Robb, J. A. and Forbes, G. B. (1948). Amer. J. Dis. Child., 76, 648.

Wells, E. F. (1889). J. Amer. med. Ass., 12, 187. 